\title{
Y-12
}

Y/ER-19R-2

(Revision of Y/TS-347/1R3)

OAK RIDGE

Y-12

PLANT

MARTIN MARUETRA

\section{Revised RCRA Closure Plan for the Interim Drum Yard (S-030) at the Oak Ridge Y-12 Plant, Oak Ridge, Tennessee}

SEPTENAER, 1994

RECEIVED

NOV 041996

OSTI

MANAGED BY

MARTIN MARIETTA ENERGY SYSTEMS, INC.

FOR THE UNITED STATES

DEPARTMENT OF ENERGY 


\section{DISCLAIMER}

Portions of this document may be illegible in electronic image products. Images are produced from the best available original document. 


\section{DISCLAIMER}

This report was prepared as an account of work sponsored by an agency of the United States Government. Neither the United States Government nor any agency thereof, nor any of their employees, makes any warranty, express or implied, or assumes any legal liability or responsibility for the accuracy, completeness, or usefulness of any information, apparatus, product, or process disclosed, or represents that its use would not infringe privately owned rights. Reference herein to any specific commercial product, process, or service by trade name, trademark, manufacturer, or otherwise does not necessarily constitute or imply its endorsement, recommendation, or favoring by the United States Government or any agency thereof. The views and opinions of authors expressed herein do not necessarily state or reflect those of the United States Government or any agency thereof. 
Environmental Restoration Division Y-12 Environmental Restoration Program

Revised RCRA Closure Plan for the Interim Drum Yard (S-030) at the Oak Ridge Y-12 Plant, Oak Ridge, Tennessee

C. M. Smith

Project Manager

Date Issued-September, 1994

Prepared For

U.S. Department of Energy

Office of Environmental Restoration and Waste Management

Prepared by

Oak Ridge Y-12 Plant

Oak Ridge, Tennessee 37831-8169

managed by

MARTIN MARIETTA ENERGY SYSTEMS, INC.

for the

U.S. DEPARTMENT OF ENERGY

under Contract DE-AC05-84OR21400 
CONTENTS

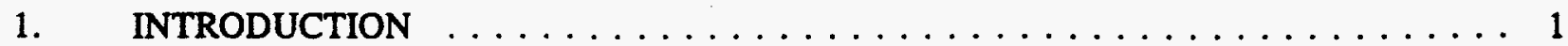

$1.1 \quad$ FACILITY DESCRIPTION $\ldots \ldots \ldots \ldots \ldots \ldots \ldots \ldots \ldots \ldots \ldots \ldots$

1.2 WASTE INVENTORY $\ldots \ldots \ldots \ldots \ldots \ldots \ldots \ldots \ldots \ldots$

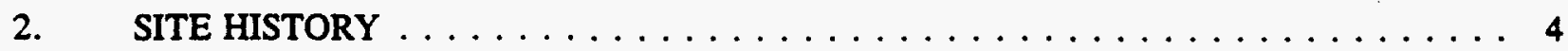

2.1 PARTIAL CLOSURE OF THE SOUTHERN PORTION OF IDY $\ldots \ldots \ldots \ldots$

2.2 WASTE REMOVAL AND FACILITY DECOMMISSIONING $\ldots \ldots \ldots \ldots$

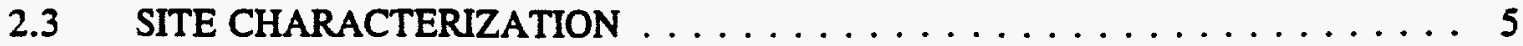

3. CLOSURE PERFORMANCE STANDARDS $\ldots \ldots \ldots \ldots \ldots \ldots$

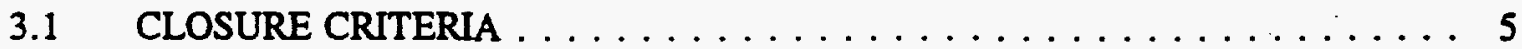

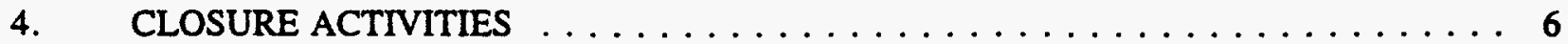

4.1 PHASE I CLOSURE- BEFORE CLOSURE PLAN APPROVAL $\ldots \ldots \ldots$

4.2 PHASE II CLOSURE - AFTER CLOSURE PLAN APPROVAL $\ldots \ldots \ldots \ldots$

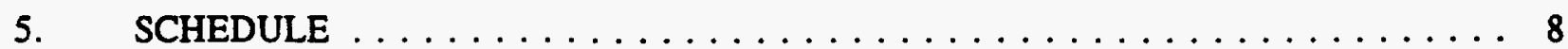

6. POSTCLOSURE CARE $\ldots \ldots \ldots \ldots \ldots \ldots \ldots \ldots \ldots \ldots \ldots \ldots$

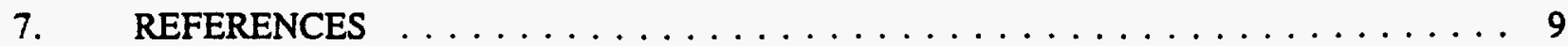

APPENDICES

I. FIELD INVESTIGATION $\ldots \ldots \ldots \ldots \ldots \ldots \ldots \ldots \ldots \ldots \ldots \ldots$

II. SITE CHARACTERIZATION DATA SUMMARY $\ldots \ldots \ldots \ldots \ldots \ldots \ldots$ II-1 


\section{ACRONYMS}

CERCLA Comprehensive Environmental Response, Compensation, and Liability Act DOE U.S. Department of Energy

EP Extraction Procedure

EPA U.S. Environmental Protection Agency

ER Environmental Restoration

FFA Federal Facilities Agreement

IDY Interim Drum Yard

PCBs Polychlorinated Biphenyls

RCRA Resource Conservation and Recovery Act

TCLP Toxicity Characteristic Leachate Procedure

TDEC Tennessee Department of Environment and Conservation

TSCA Toxic Substances Control Act

TSD Treatment, Storage, and Disposal 


\subsection{INTRODUCTION}

This closure plan has been prepared for the Interim Drum Yard (S-030) located at the Y-12 Plant in Oak Ridge, Tennessee. The plan outlines the actions required to achieve closure of Interim Drum Yard (IDY) unit and is being submitted in accordance with TN Rule 1200-1-11.05(7) and 40 CFR \$265.110. The IDY facility has been used to store waste materials which are regulated by the Resource Conservation and Recovery Act (RCRA).

\subsection{Facility Description}

The IDY facility was a containerized waste storage area located in the confines of the Y-12 Plant exclusion area. The location of the yard at the Y-12 Plant is shown in Figure 1. The dimensions are shown in Figure 2. The facility originally consisted of an open yard paved with gravel. Drummed waste was stored on pallets. Two tent facilities were later constructed to cover the drums. Inside the tents, plywood was laid down and covered with plastic to form diking with 6-inch curbs to act as secondary containment. The size of each diked area was approximately $70 \times 50$ feet. The drums were placed on pallets and double-stacked to accommodate a total storage capacity of 1,000 x 55-gallon drums.

\subsection{Waste Inventory}

The maximum waste inventory at the Interim Drum Yard was approximately 55,000 gallons, or 1,000 drums.

Typical hazardous wastes stored at the unit include:

-mercury-contaminated solids and sludges;

-chromium-contaminated cooling tower sludge;

-electrochemical machining sludges;

cadmium plating wastes;

-solids contaminated with halogenated solvents (freon, methylene, chloride, perchloroethylene); waste water treatment sludges and carbon;

acetonitrile;

-polychlorinated biphenyl (PCB) contaminated solids;

-asbestos;

uranylnitrate solutions. 


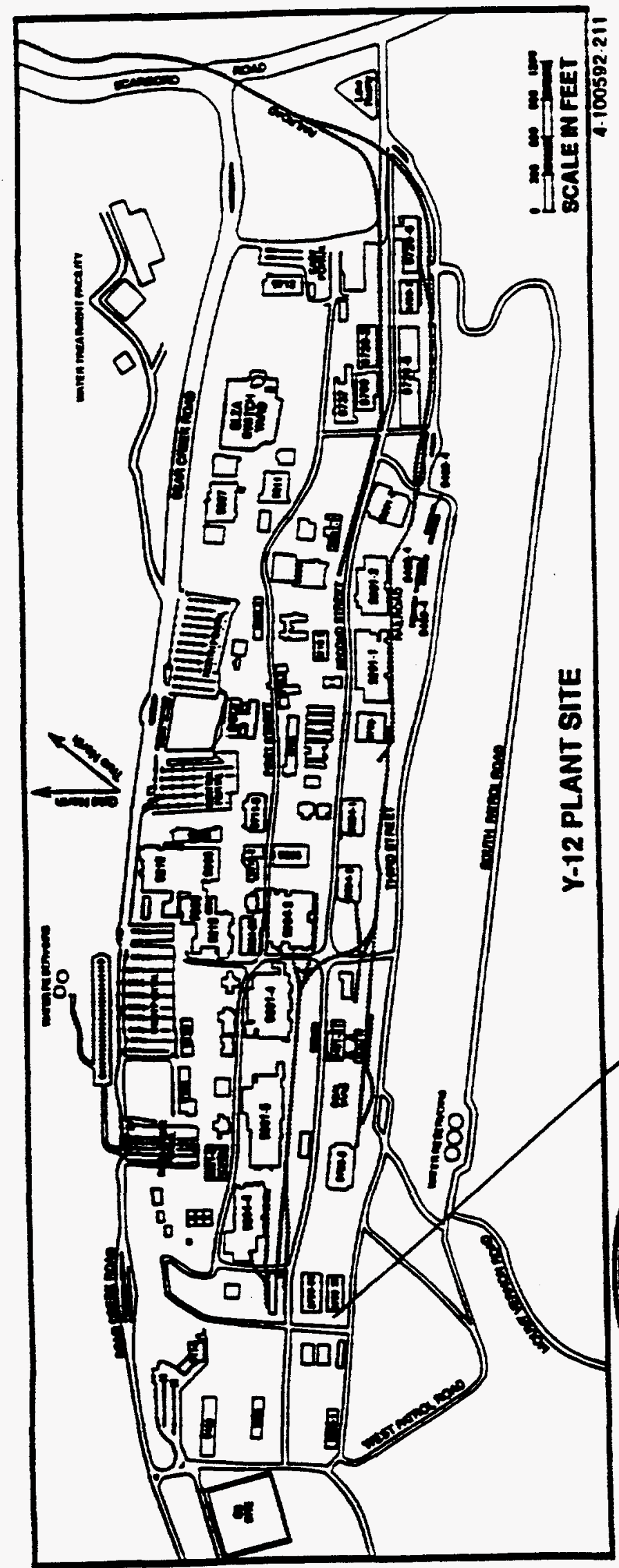

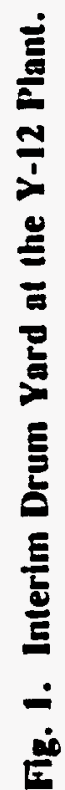




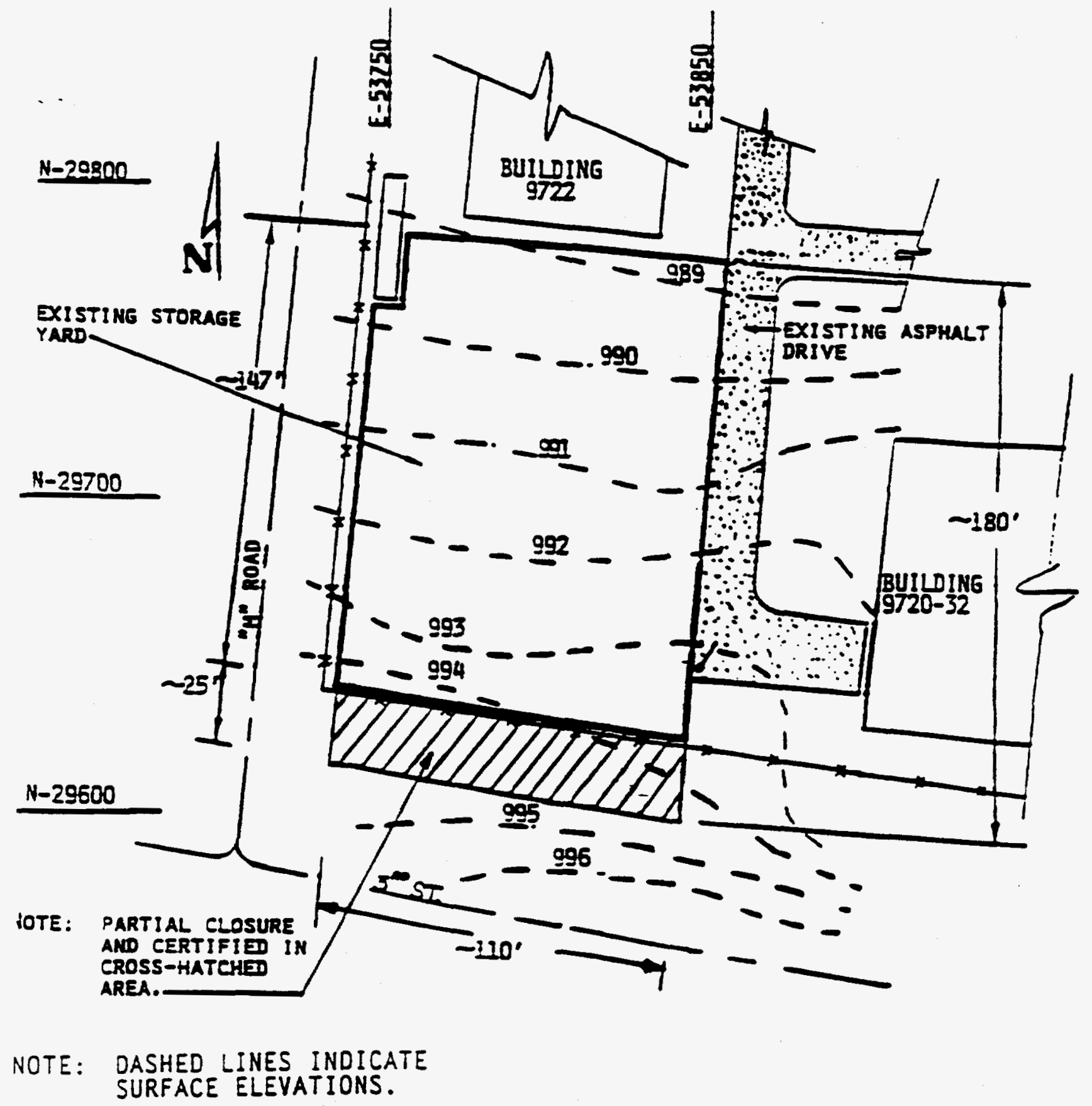

Fig. 2. Site map of the DY. 


\subsection{SITE HISTORY}

The Interim Drum Yard originally started receiving waste in 1984 . The facility was covered by tent facilities in 1989. The facility operated under interim status of the RCRA regulations until such status ran out on November 8, 1992. All waste stored at this site was transferred to another RCRA permitted facility.

\subsection{Partial Closure of the Southern Portion of IDY}

A 25-ft wide strip on the south edge of the Interim Drum Yard was closed in 1987. The partial closure was accepted by TDEC (Reference 3). The closure plan, RCRA Closure Plan for the Interim Drum Yard (S-030) at the Oak Ridge Y-12 Plant [Y/TS-347/1 (Energy Systems 1986)], was submitted in 1986 to DOE for review and transmittal to the Tennessee Department of Environment and Health (TDEH). The closure plan indicated that the southem portion of the IDY would be closed to accommodate a high priority project scheduled to be constructed during 1987. Soil sampling activities described in the closure plan for partial closure were initiated during November of 1986 (Bohrman et al. 1988).

The exposed concrete pad was sampled during November and December of 1986 . Seven composite samples were obtained from seven randomly selected grid squares. Contaminants analyzed for in the samples were below the maximum allowable limits for the respective contaminants specified in the approved closure plan. The exposed concrete pad was broken up and transported to the Y-12 Plant Burial Ground A in September, 1987.

A soil sampling program was initiated in the southem portion of the IDY during November, 1986. The program consisted of five boreholes and seven composite surface samples. During the sampling activities, two buried concrete pads were discovered in the area to be closed. A revised RCRA Closure Plan for the Interim Drum Yard (S-030) at the Oak Ridge Y-12 Plant (Y/ER-19) was prepared and submitted to DOE and TDEH. The revised plan indicated that additional boreholes would be drilled around the buried pads. Eight additional boreholes were drilled around the buried pads during February and March of 1987.

Analytical sample results showed that only cadmium exceeded the maximum allowable limits established in the approved closure plan. The cadmium contamination was found in the upper two feet of soil and gravel immediately above the two buried concrete pads. The soil and gravel above the pads, the two buried pads, a thin layer [15 to $30 \mathrm{~cm}$ (6 to $12 \mathrm{in.}$ )] of soil and gravel beneath the pads, and the soil around the pads were excavated between August 7 to 10,1987 . Approximately $268 \mathrm{~m}^{3}$ (350 $\mathrm{yd}^{3}$ ) of soil, gravel, and concrete were excavated and transported to the East Chestnut Ridge Waste Pile.

\subsection{Waste Removal and Facility Decommissioning}

With interim status terminating November 8,1992 , it was determined to remove all containerized waste and submit a closure plan, for IDY. All waste stored at the facility was either shipped off-site for final disposal or transferred to a RCRA-permitted storage facility within the Oak Ridge Reservation by October, 1992.

In order to prepare the site for the sampling activities of the closure plan, the tent structures and all plastic diking were dismantled and disposed in 1993. 


\subsection{Site Characterization}

Pre-approval by TDEC was granted to prepare the site and perform site characterization before issuance of an approved closure plan (Reference 2). The site characterization was performed January through March of 1994. The steps taken are outlined in Section 5 of this closure plan. Summary results presented in Appendix II indicated that the site has some contamination above closure criteria for cadmium and mercury.

\subsection{CLOSURE PERFORMANCE STANDARD}

The closure performance standards that all closure activities at the Interim Drum Yard must meet are specified in TN Rule 1200-1-11-.05(7)(b) and 40 CFR \$265.111. These standards require that closure activities minimize the need for further maintenance, minimize or eliminate the release of hazardous constituents from the unit(s), and comply with all applicable closure requirements specified in the regulations (TN Rule 1200-1-11-.05 and 40 CFR Part 265). The applicable requirements for the site are found in TN Rule 1200-1-11-.05(100) and 40 CFR \$265.197. Specific closure criteria for soils and equipment are shown in Table 1.

The closure activities in this closure plan meet these requirements by removing the containerized waste and by testing to demonstrate that the storage of hazardous wastes in the facility has not resulted in a release of hazardous constituents that would endanger human health or the environment. These closure activities will remove the units from RCRA regulation.

\subsection{Closure Criteria}

As detailed in the steps of Section 4, all stored waste was removed from the site and properly dispositioned. The tent and diking structures were removed and the gravel area sampled per the Sampling Plan of Appendix I. The results of this data were then compared to the following closure criteria. The closure criteria was developed from two EPA documents: EPA 530/SW-89-03 RCRA Facility Investigation (RFI) Guidance, May, 1989; and the proposed subpart S requirements published in the July 27, 1990 Federal Register "Corrective Action Solid Waste Management Units (SWMUs) at Hazardous Waste Management Facilities." When limits differed, the most conservative limit was chosen.* Due to lack of reference for lead and selenium, the TCLP limit was utilized for the criteria for these metals. If total ICP metals analysis was not 20 times the TCLP limit for these metals, a TCLP

analysis was not performed. The PCB limit was derived from the soil clean-up criteria of $40 C F R$ 761.125 . 


\section{TABLE I}

\section{Contaminants for Which Soil Will Be Analyzed and Their Closure Criteria}

\section{Contaminant}

Arsenic

Cadmium

Chromium

Cyanide

Freon (dichlorodifluoromethane)

Lead (TCLP)

Mercury

Methylene Chloride

Nickel

Perchloroethylene (tetrachloroethylene)

PCBs

Selenium (TCLP)

Silver

\section{Concentration Limit}

$$
\begin{gathered}
80 \mathrm{mg} / \mathrm{kg} \\
40 \mathrm{mg} / \mathrm{kg} \\
400 \mathrm{mg} / \mathrm{kg} \\
2,000 \mathrm{mg} / \mathrm{kg} \\
20,000 \mathrm{mg} / \mathrm{kg} \\
* 5 \mathrm{mg} / \mathrm{kg} \\
20 \mathrm{mg} / \mathrm{kg} \\
90 \mathrm{mg} / \mathrm{kg} \\
2,000 \mathrm{mg} / \mathrm{kg} \\
10 \mathrm{mg} / \mathrm{kg} \\
25 \mathrm{mg} / \mathrm{kg} \\
* 1 \mathrm{mg} / \mathrm{kg} \\
200 \mathrm{mg} / \mathrm{kg}
\end{gathered}
$$

\subsection{CLOSURE ACTIVITIES}

As described in Section 2, Site History, some of the closure activities were performed prior to approval of this closure plan at the approval of the State Regulators.

\subsection{Phase I Closure - Before Closure Plan Approval}

1. Confirm that all containerized waste was removed from the site and properly handled under state and federal RCRA regulations.

2. Disassemble the tent structures and properly dispose.

3. Disassemble the dike structures and properly dispose.

4. Initiate Phase I soil sampling and analysis program as outlined in Appendix I.

5. Evaluate data and compare to Table I of closure criteria. If analysis results indicate contamination over acceptable limits, proceed to Phase II closure. The results indicate $\mathrm{Hg}$ contamination over limits at a surface sample and cadmium contamination in a sample at a 1-3.0 ft sample. See Appendix II for data summary. 


\subsection{Phase II Closure - After Closure Plan Approval - Site Remediation}

1. The area contaminated with mercury on the surface shall be over excavated to approximately a $1-\mathrm{ft}$ depth with a minimal hoie diameter of 2 feet.

2. The area which had cadmium limits above closure criteria was in a core sample in the 1 to $3-\mathrm{ft}$ range. This area shall be over excavated to approximately the 4-ft level with a minimal hole diameter of 2 feet.

3. The excavated soil shall be packaged separately and properly dispositioned in a RCRA permitted facility.

4. Each excavation site will be re-characterized. The sampling shall consist of three core samples per excavation site. Sampling sites shall be one at the bottom of the hole and two separate samples within 6 inches of top rim of the hole. Each site will be re-characterized only for the contaminant for which the excavation was indicated to verify clean-up.

5. If the confirmation samples indicate the sites do not have contamination at leveis above the closure criteria. the site shall be considered clean and the excavation site may be backfilled with clean fill.

6. If the confirmation samples indicate that the sites still have contamination above closure criteria, the excavation sites can be further over excavated 1 foot past the identified contamination and steps 3,4 , and 5 repeated.

After three attempts at over excavation, the site will be closed with contamination in place. The excavated areas will be backfilled with clean fill material, and any further investigatory or remedial action will be conducted under the authority of the existing Federal Facilities Agreement (FFA) between DOE, the Tennessee Department of Environment and Conservation (TDEC), and the Environmental Protection Agency (EPA). Subsequent investigations or other pertinent environmental activities will be conducted by the Y-12 Environmental Restoration Program as part of the ongoing Comprehensive Environmental Response. Compensation, and Liability Act (CERCLA) activities. If required. these actions will be conducted in lieu of the requirements found in 40 CFR 265.197(b) and TN Rule 1200-1-11-.05(h)(2). Groundwater contamination is being assessed by the Y-12 Plan Comprehensive Groundwater Program.

7. All equipment shall be decontaminated by use of a pressure washer and verified clean by use of a radiation monitor to $\mathrm{Y}-12$ Plant standards.

8. Prepare a written report to summarize closure activities.

9. Closure will be certified by an independent professional engineer within 60 days of completion. The certification, along with the closure report, will then be submitted to the Commissioner of TDEC for closure approval. 


\subsection{SCHEDULE}

The estimated schedule for closure of the Interim Drum Yard is shown in Table II. Phase I of the closure activities has been completed. Phase II of the closure activities will begin after the closure plan has been approved.

The schedule presented for the closure of this facility is an estimate, subject to factors such as weather conditions and actual boundaries of contamination. When the schedule cannot be met, a revised schedule will be submitted to the Tennessee Department of Environmental Conservation (TDEC).

\section{TABLE II}

\section{Closure Schedule for Interim Drum Yard}

\begin{tabular}{lcc} 
Activity & $\begin{array}{c}\text { Activity Duration } \\
\text { (Days) }\end{array}$ & $\begin{array}{c}\text { Cumulative } \\
\text { Days }\end{array}$ \\
\hline $\begin{array}{l}\text { Confirm removal of stored waste, } \\
\text { disassemble tent and dike structure } \\
\text { and dispose }\end{array}$ & Complete & Complete \\
·Perform Phase I sampling & Complete \\
-Receive Closure Plan approval & 0 & Complete \\
-Excavate hot spot contamination & 80 & 0 \\
-Perform verification sampling/analysis & 40 & 80 \\
-Write Closure Report & 40 & 120 \\
-Obtain certification from Independent & 20 & 160 \\
Professional Engineer & & 210 \\
-DOE review closure and submit to TDEC & 30 &
\end{tabular}




\subsection{POST CLOSURE CARE}

Remediation activities of this closure plan are intended to clean up any RCRA hazardous contaminants which may have resulted from storage activities associated with the IDY facility. Upon successful completion of cleanup activities and certification/approval of the TDEC Commissioner, this site will be retumed to plant activities and not subject to any further requirements under 40 CFR 265 or TN Rules 1200-1.05. However, should contamination of the surrounding environment media be found, DOE proposes to conduct any investigatory or remedial actions required under the authority of the existing FFA. Subsequent investigation or other pertinent environmental activities will be conducted by the ER program as part of the ongoing CERCLA activities at the $\mathrm{Y}-12$ plant. If required, these actions will be conducted in lieu of the requirements found in 40 CFR 265 or TN Rule 1200-1.05.

\subsection{REFERENCES}

1. RCRA Closure Plan for the Interim Drum Yard, Y/TS-347/1, Energy Systems.

2. Letter, "TDEC Approval to Start Sampling," S. Lankford, DOE to E. Cox, TDEC, November, 1993.

3. RCRA Facility Investigation Guidance, May, 1989, EPA, 530/SW-89-03.

4. July 27, 1990 Federal Register, "Corrective Action Solid Waste Management Units (SWMUs) at Hazardous Waste Management Facilities"

5. 40 CFR 761, "Polychlorinated Bi-Phenyls (PCBs) Manufacturing, Processing, Distribution in Commerce, and Use Prohibitions." 


\section{APPENDIX I}

\section{FIELD INVESTIGATION}


Appendix I

\section{FIELD INVESTIGATION}

The field investigation for the IDY was conducted from January 3 to January 29,1994 . The overall objective of the investigation was to support closure activities at IDY by providing data that define the nature and extent of contamination at the unit. Data obtained from this investigation will define the potential for clean closure of the unit. If clean closure is not practical, the data obtained during this investigation will provide preliminary characterization of the site that will serve as a basis for further investigations and implementation of corrective action. The investigation was conducted in accordance with approved project-specific work plans including the Health and Safety Plan (Y/ER-132), Mobilization Plan (Y/ER-134), Quality Assurance Project Plan (QAPjP)(Y/ER-133), and Waste Management Plan (Y/ER-135).

Mobilization to the site occurred on January 3 and 4, 1994. A decontamination and equipment staging area was established south of the site, as specified by the Martin Marietta Energy Systems, Inc. (Energy Systems) Technical Lead and Project Manager. Prior to the initiation of sampling, inspections of the drill rig and sampling equipment were conducted by personnel from the $Y-12$ Plant Health Physics, Industrial Safety, and Industrial Hygiene departments.

Soil sampling began on January 6, 1994. During the investigation, collected samples were scanned for radiological contamination by Y-12 Plant Health Physics personnel and were then hand carried to the Y-12 Analytical Services Organization (ASO). Sampling was completed on January 29 , 1994. At the completion of sampling, all equipment was decontaminated and the decontamination pad was disassembled. Soil cuttings that could not be used in borehole abandonment were carefully spread around the borehole from which they were derived. After green-tagging as free of radiological contamination by Health Physics personnel, all equipment was removed from the site.

Prior to sampling, an exclusion and contamination reduction zone was established at the entire site using caution tape. A defined entry/exit corridor as also established to control the potential spread of contaminants to clean areas. A summary of shallow soil sample numbers, sampling method, and sampling interval is presented in Table 1.

\section{SURFACE AND SUBSURFACE CHARACTERIZATION}

A statistically derived sampling methodology was used to define the required number of samples and their locations for investigation of the surface and subsurface soils. In order to implement a statistical approach, a grid system was developed over a plan playout of the site. A variety of grid dimensions were considered ranging from $.6 \times .6 \mathrm{~m}$ to $6 \times 6 \mathrm{~m}(2 \times 2 \mathrm{ft}$ to $20 \times 20 \mathrm{ft})$ grids. The specific grid dimensions considered were $0.6 \times 0.6 \mathrm{~m}(2 \times 2 \mathrm{ft}) ; 1.5 \times 1.5 \mathrm{~m}(5 \times 5 \mathrm{ft}) ; 2.4 \times 2.4 \mathrm{~m}(8 \times 8 \mathrm{ft}) ; 3 \times$ $3 \mathrm{~m}(10 \times 10 \mathrm{ft}) ; 3 \times 3.7 \mathrm{~m}(10 \times 12 \mathrm{ft}) ; 4.6 \times 4.6 \mathrm{~m}(15 \times 15 \mathrm{ft}) ;$ and $6 \times 6 \mathrm{~m}(20 \times 20 \mathrm{ft})$.

In order to select grid dimensions, both the statistically required number of samples resulting from each set of grid dimensions and the logistics of field sampling requirements were considered. No historical data were available to base the required samples on variability limits and, therefore, ASTM Method D-140-70 was used. This method bases the required number of samples for a population of grids, drums, etc., on the cube root of the total number of items in the population. Table 2 provides the 
number of samples required by ASTM D140-70 for each of the various grid dimensions considered in formulation of the sampling methodology using a simple random sampling approach. Simple random sampling is based on the premise that each randomly selected sampling location is equally representative of the characteristics of the population.

Although the smaller grids provide a greater number of samples, grids with dimensions of less than $2.4 \times 2.4 \mathrm{~m}(8 \times 8 \mathrm{ft})$ were considered to present logistical problems for sample collection activities. Grids with dimensions of $3 \times 3 \mathrm{~m}(10 \times 10 \mathrm{ft})$ or $3 \times 3.7 \mathrm{~m}(10 \times 12 \mathrm{ft})$ provide an equal number of random samples without presenting logistical problems; the latter size was selected because it minimized the number of fractional grids. Therefore, for a simple random sampling strategy, six samples would be required for initial characterization of the soils.

A stratified random sample sampling methodology was also considered for selection of the required number of samples and their locations. Stratified random sampling recognizes that certain sitespecific factors influence the probability of a given area exhibiting contamination. For example, stratified sampling provides for a greater number of samples in downgradient areas (where contamination is most likely) than in upgradient areas of a site. In order to apply a stratified sampling approach, the site was divided into three strata based on a qualitive estimate of the probability of contamination. The area upgradient to the buried pad and adjacent to the closed portio of the $\mathrm{Y}-030$ was defined as the first stratum. The second stratum was defined as the area above and surrounding the buried concrete pad, and the remaining downgradient area within $Y-030$ was defined as the final stratum. The second and third strata were considered to have the highest priority of contamination.

The required number of samples were determined using the previously described grid system and ASTM D140-70. Application of the stratified random sampling methodology resulted in three samples for the upgradient zone and four samples in the area surrounding the pad. This method identified the need for five samples in the downgradient zone.

Stratified random sampling was selected over a simple random method because it provided a greater number of samples in the areas of the site most likely to be contaminated. Therefore, a total of 12 sample locations was selected.

A random number table was used to select the specific sampling locations within the three strata. Figure 4 depicts the site grid system and randomly selected sampling locations.

Soil samples were collected at 12 surface and 12 subsurface locations (Figs. 5 and 6). Boreholes were completed as closely as possible to the general locations specified in the Sampling and Analysis Plan. However, due to the presence of overhead utilities and other obstructions, several boreholes had to be moved from their original locations. Because auger refusal was encountered at $1.4 \mathrm{~m} \mathrm{(4.75} \mathrm{ft}$ ) below ground surface (BGS) in borehole SB-01 only one sample was collected from this location for analysis. Boreholes SB-02 through SB-06 were terminated at the water table interface. Boreholes SB-07 through SB-12 were terminated at $20 \mathrm{ft}$ BGS or refusal in an attempt to determine bedrock depth.

A majority of the soil samples collected during the investigation consisted of yellowish brown to light olive gray clayey silt or silty clay with some gravel clasts of light to dark olive grey shale and light grey limestone. Clays were moist with medium plasticity. Lithologic logs presenting the subsurface geology data for each borehole are included in Appendix A. 
Table 1. Summary of shallow soil sample numbers, method, and sample depths

\begin{tabular}{|c|c|c|c|}
\hline $\begin{array}{l}\text { Burehole } \\
\text { number }\end{array}$ & $\begin{array}{l}\text { Sample } \\
\text { number }\end{array}$ & $\begin{array}{l}\text { Sample interial } \\
\text { (n BGS) }\end{array}$ & $\begin{array}{l}\text { Sanıpling } \\
\text { method }\end{array}$ \\
\hline ss ! & DSO011 & $0.0-1.0$ & scoop \\
\hline SS-2 & DS0021 & $0.0-1.0$ & scoop \\
\hline SS-3 & DSO031 & $0.0-1.0$ & scoop \\
\hline SS 4 & DSO04I & $0.0-1.0$ & scoop \\
\hline SS-5 & DS0051 & $0.0-1.0$ & scoop \\
\hline SS-6 & DSO061 & $0.0-1.0$ & scoop \\
\hline SS-6 & $D S 1061^{\circ}$ & $0.0-1.0$ & scoop \\
\hline SS-6 & DS06D电 & $0.0-1.0$ & scoop \\
\hline SS-7 & DS0071 & $0.0-1.0$ & scoop \\
\hline SS-8 & DS0081 & $0.0-1.0$ & scoop \\
\hline SS-9 & DSO091 & $0.0-1.0$ & scoop \\
\hline SS-10 & DSOIOI & $0.0-1.0$ & scoop \\
\hline SS-11 & DSOIII & $0.0-1.0$ & scoop \\
\hline SS-12 & DSO121 & $0.0-1.0$ & scoop \\
\hline
\end{tabular}

- Duplicate of sample DSO061.

Table 2. Required number of samples vs. grid dimensions considered in surface soil sampling mahodology

\begin{tabular}{lcc}
\hline Grid dimensions & $\begin{array}{c}\text { Tocal number } \\
\text { of grids }\end{array}$ & $\begin{array}{c}\text { Required number of } \\
\text { sample }\end{array}$ \\
\hline $6 \times .6 \mathrm{~m}(2 \times 2 \mathrm{ft})$ & 3963 & 16 \\
$1.5 \times 1.5 \mathrm{~m}(5 \times 5 \mathrm{f})$ & 634 & 9 \\
$2.4 \times 2.4 \mathrm{~m}(8 \times 8 \mathrm{ft})$ & 247 & 7 \\
$3 \times 3 \mathrm{~m}(10 \times 10 \mathrm{ft})$ & 159 & 6 \\
$3 \times 3.7 \mathrm{~m}(10 \times 12 \mathrm{ft})$ & 132 & 6 \\
$4.6 \times 4.6 \mathrm{~m}(15 \times 15 \mathrm{ft})$ & 71 & 5 \\
$6 \times 6 \mathrm{~m}(20 \times 20 \mathrm{ft})$ & 40 & 4 \\
\hline
\end{tabular}


The elevation of bedrock at the northeast end of IDY is - $296.57 \mathrm{~m}$ ( $973 \mathrm{ft}$ ) above mean sea level (MSL). This measurement is based on the depth of auger refusal in two subsurface boreholes. Auger refusal was encountered at $296.69 \mathrm{~m}(973.39 \mathrm{ft})$ above MSL in borehole SB-10, and $296.47 \mathrm{~m}(972.69 \mathrm{ft})$ in borehole SB-11. The water table stabilized at depths ranging from 0.5 to $2.0 \mathrm{~m}$ ( 1.8 to $6.7 \mathrm{ft}$ ) BGS across the site. These depths were influenced by heavy precipitation in the form of rain and melting snow and are believed to represent perched conditions.

\section{SURFACE SOIL SAMPLING}

At each of 12 sampling locations, shallow soil samples were collected as deep as $0.3 \mathrm{~m}(1.0 \mathrm{ft})$ using a hand scoop (see Fig. 5). Prior to sample collection, the top $5 \mathrm{~cm}$ (2 in.) of overlying gravel was removed from the sampling point. Sufficient sample volume was then collected to fill containers for the following analysis:

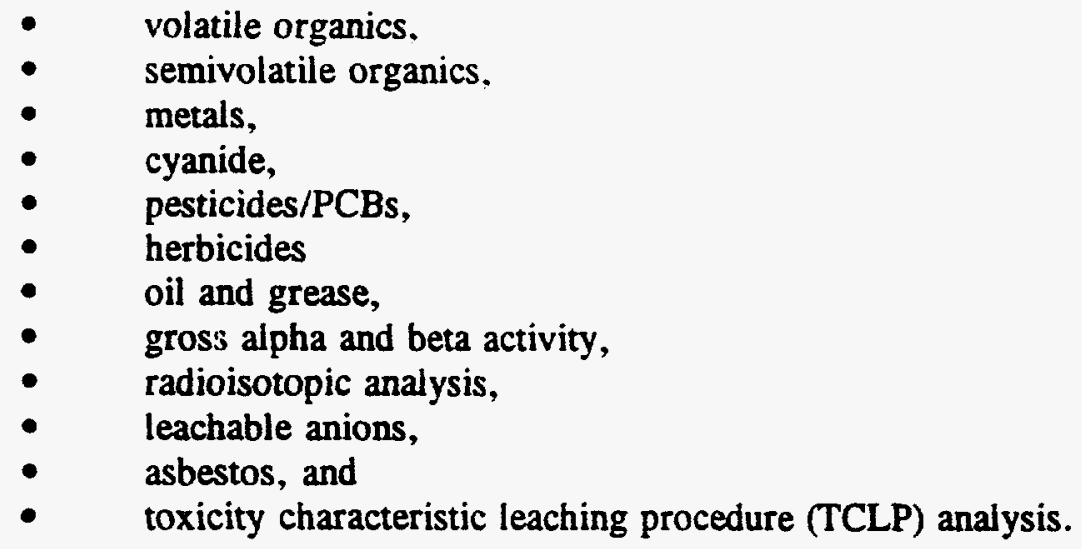

\section{SUBSURFACE SOIL SAMPLING}

At each of the 12 subsurface soil sampling locations, deep soil samples were collected using hollow-stem auger drilling and split-spoon samplers (Fig. 6). Subsurface soil samples were collected at depths of $0.3,0.9,1.5,3$, and $4.6 \mathrm{~m}(1,3,5,10$ and $15 \mathrm{ft})$. These sampling depths were selected to support the objectives stated in the Field Sampling and Analysis Plan. A sampling depth of $0.3 \mathrm{~m}$ ( $1 \mathrm{ft}$ ) was selected to provide supplemental data concerning shallow soil contamination. Samples collected at the $0.9-, 1.5-$, and 3-m (3-, 5-, and 10-ft) intervals provide data necessary to determine the practicality of clean closure. Samples at the 3- and $4.6 \mathrm{~m}(10-$ and $15 \mathrm{ft})$ intervals are used to characterize the vertical extent of contamination.

A sufficient volume of sample was collected to fill containers for the following analyses:

- volatile organics,

- semivolatile organics,

- metals,

- cyanide,

- pesticide/PCBs,

- herbicides,

- $\quad$ oil and grease, 
$\frac{1}{1}$

\begin{tabular}{|c|c|c|c|c|c|c|c|c|c|c|c|}
\hline & 1 & 2 & 3 & 4 & 5 & 6 & 7 & 8 & 9 & 10 & 11 \\
\hline & 12 & 13 & 14 & 15 & 16 & 17 & 18 & 19 & 20 & 21 & 22 \\
\hline & 23 & 24 & 25 & 26 & 27 & 28 & 29 & 30 & 31 & 32 & 33 \\
\hline & 34 & 35 & 36 & 37 & 38 & 39 & 40 & 41 & 42 & 43 & 4 \\
\hline & 45 & 46 & 47 & 48 & 49 & 50 & 51 & 52 & 53 & 54 & 55 \\
\hline & 56 & 57 & 58 & 59 & 60 & 61 & 62 & 63 & 64 & 65 & 66 \\
\hline $120^{\prime}$ & 67 & 68 & 69 & 70 & 71 & 72 & 73 & 74 & 75 & 76 & 77 \\
\hline & 78 & 79 & 80 & 81 & 82 & 83 & 84 & 85 & 86 & 87 & 88 \\
\hline & 89 & 90 & 91 & 92 & 93 & 94 & 95 & 96 & 97 & 98 & 99 \\
\hline & 100 & 101 & 102 & 103 & 104 & $105^{-}$ & 106 & 107 & 108 & 109 & 110 \\
\hline & 111 & 112 & 113 & 114 & 115 & 116 & 117 & 118 & 119 & 120 & 121 \\
\hline & 122 & 123 & 124 & 125 & 126 & 127 & 128 & 129 & 130 & 131 & 132 \\
\hline
\end{tabular}

A - Shallow soil

- Soil boring

Fig. 4. Sampling locations for surface soils and soil borings. 


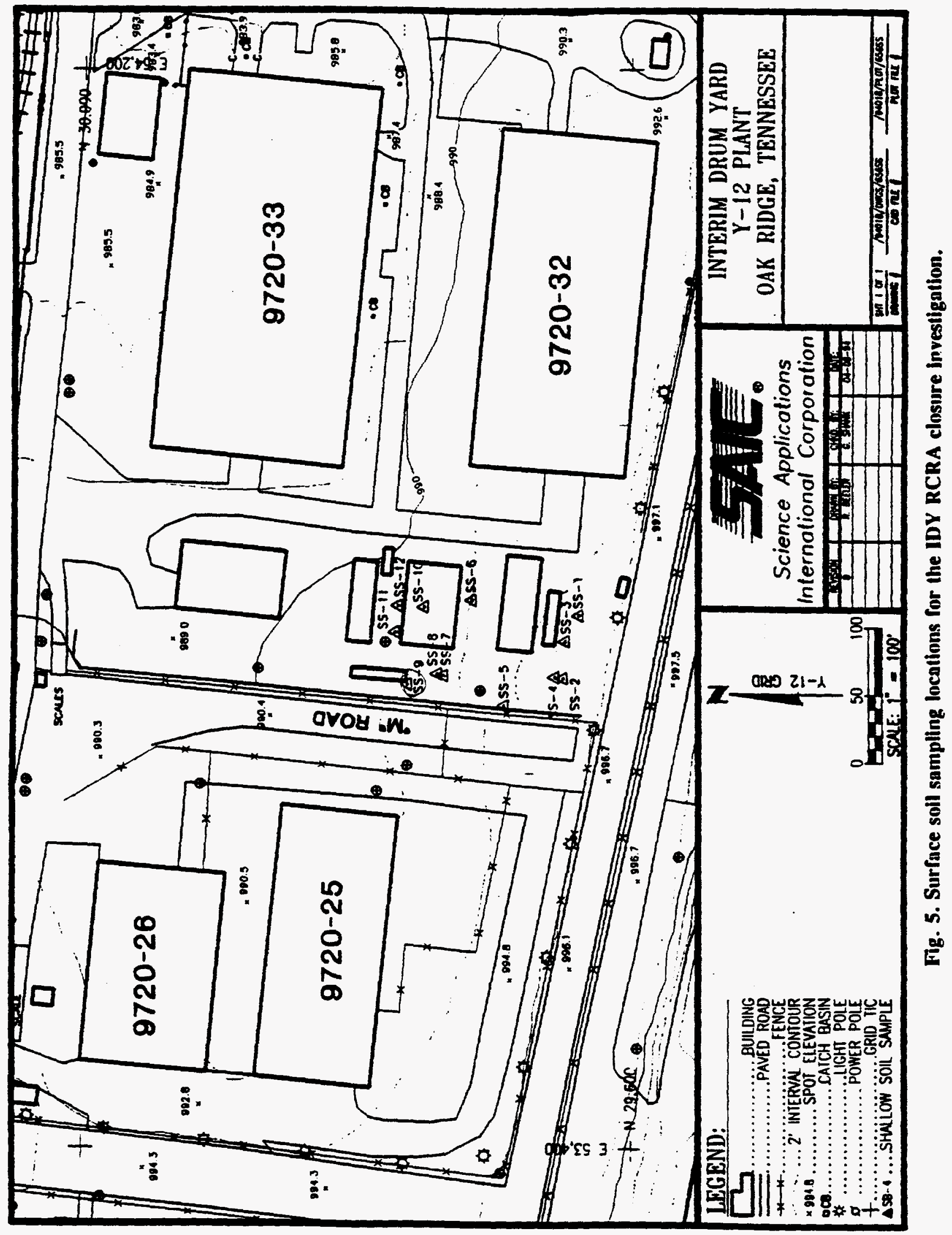




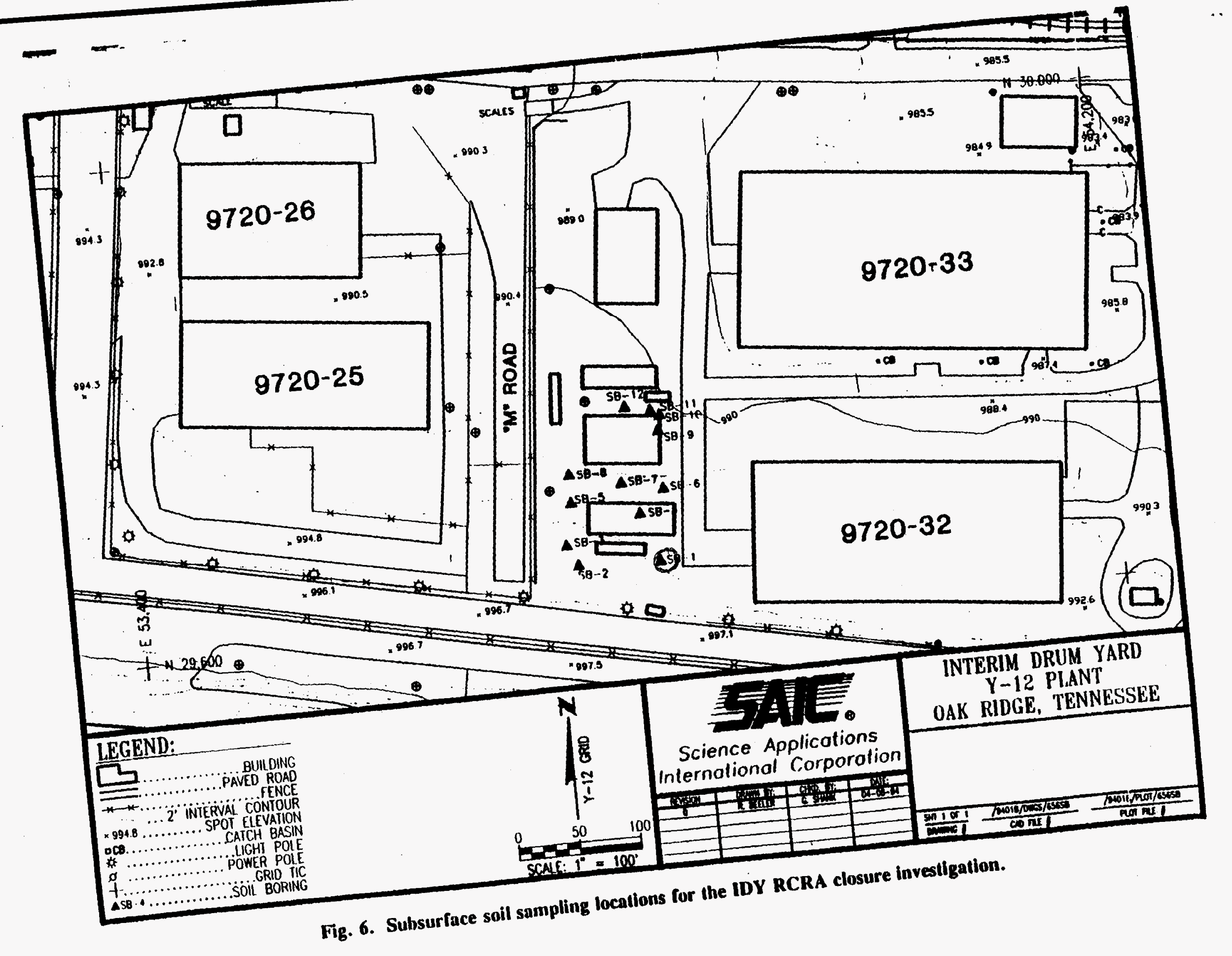


Table 3. Summary of subsurface soil sample numbers, method, and sample depths

\begin{tabular}{|c|c|c|c|}
\hline $\begin{array}{l}\text { Borebole } \\
\text { aumber }\end{array}$ & $\begin{array}{l}\text { Sample } \\
\text { number }\end{array}$ & $\begin{array}{l}\text { Sample interval } \\
\text { (ft BGS) }\end{array}$ & $\begin{array}{l}\text { Sampling } \\
\text { method }\end{array}$ \\
\hline SB-1 & DB0011 & 1.3 & Split spoon \\
\hline SB-2 & $\begin{array}{l}\text { DBO02I } \\
\text { DBO022 } \\
D B 0023 \\
D B 0024\end{array}$ & $\begin{array}{c}1.3 \\
3.5 \\
7.9 \\
10.12\end{array}$ & $\begin{array}{l}\text { Split spoun } \\
\text { Split spoon } \\
\text { Split spoon } \\
\text { Split spexin }\end{array}$ \\
\hline SB-3 & $\begin{array}{l}\text { DB0031 } \\
\text { DB0032 } \\
\text { DB103 } \\
\text { DB0033 }\end{array}$ & $\begin{array}{l}1-3 \\
3-5 \\
3-5 a \\
5-7\end{array}$ & $\begin{array}{l}\text { Split spoon } \\
\text { Split spoon } \\
\text { Split spoon } \\
\text { Split spoon }\end{array}$ \\
\hline $\mathrm{SB}-4$ & DBO041 & 1.2 & Split spoon \\
\hline SB-S & $\begin{array}{l}\text { DB0051 } \\
\text { DBC052 } \\
\text { DB0053 } \\
\text { DB0054 }\end{array}$ & $\begin{array}{c}1.3 \\
3.5 \\
5.7 \\
10.12\end{array}$ & $\begin{array}{l}\text { Split spown } \\
\text { Split spoon } \\
\text { Split spoon } \\
\text { Split spoon }\end{array}$ \\
\hline SB-6 & $\begin{array}{l}\text { DB0061 } \\
\text { DBO062 } \\
\text { DBO063 }\end{array}$ & $\begin{array}{l}1-3 \\
3-5 \\
5-7\end{array}$ & $\begin{array}{l}\text { Split spown } \\
\text { Split spoun } \\
\text { Split spown }\end{array}$ \\
\hline SB-7 & $\begin{array}{l}\text { DB0072 } \\
\text { DB0073 } \\
\text { DB0074 } \\
\text { DB0075 }\end{array}$ & $\begin{array}{l}3-5 \\
5-7 \\
10-12 \\
15-17\end{array}$ & $\begin{array}{l}\text { Split spoon } \\
\text { Split spoon } \\
\text { Split spown } \\
\text { Split spexon }\end{array}$ \\
\hline SB. 3 & $\begin{array}{l}\text { DBO081 } \\
\text { DBO08: } \\
\text { DB008: } \\
\text { DB0084 } \\
\text { DB0085 }\end{array}$ & $\begin{array}{c}1-5 \\
\vdots-5 \\
5-7 \\
10-12 \\
15-17\end{array}$ & $\begin{array}{l}\text { Split puxin } \\
\text { Split spxon } \\
\text { Split >pionn } \\
\text { Split spown } \\
\text { Split spoxn }\end{array}$ \\
\hline SB-9 & $\begin{array}{l}\text { DB0091 } \\
\text { DB109 } \\
\text { DB009? } \\
\text { DB0093 } \\
\text { DB0094 } \\
\text { DB0095 }\end{array}$ & $\begin{array}{l}1-3 \\
1-34 \\
5-5 \\
5-7 \\
10-12 \\
15-17\end{array}$ & $\begin{array}{l}\text { Spiti spixin } \\
\text { Split spexil } \\
\text { Split spex)! } \\
\text { Split spex) } \\
\text { Split spoon } \\
\text { Split spex) }\end{array}$ \\
\hline$S B-10$ & $\begin{array}{l}\text { DB0101 } \\
\text { DB0102 } \\
\text { DB0103 } \\
\text { DB0104 } \\
\text { DB0105 }\end{array}$ & $\begin{array}{c}1-3 \\
3-5 \\
5-7 \\
10-12 \\
15-17\end{array}$ & $\begin{array}{l}\text { Split spuon } \\
\text { Split spoon } \\
\text { Split spoon } \\
\text { Split spoon } \\
\text { Split spoon }\end{array}$ \\
\hline
\end{tabular}


Table 3 (continued)

\begin{tabular}{cccc}
\hline $\begin{array}{c}\text { Borehole } \\
\text { number }\end{array}$ & $\begin{array}{c}\text { Sample } \\
\text { number }\end{array}$ & $\begin{array}{c}\text { Sample interval } \\
\text { (ff BGS) }\end{array}$ & $\begin{array}{c}\text { Sampling } \\
\text { method }\end{array}$ \\
\hline SB-11 & DB0111 & $1-5$ & Split spoon \\
& DB0112 & $5-5$ & Split spoon \\
& DB0113 & $5-7$ & Split spoon \\
& DB0114 & $10-12$ & Split spoon \\
& DB0115 & $15-17$ & Split sporn \\
SB-12 & DB0121 & $1-5$ & Split spoon \\
& DB0122 & $5-5$ & Split spoon \\
& DB0123 & $5-7$ & Split spoon \\
& DB0124 & $10-12$ & Split spoon \\
& DB0125 & $15 \cdot 17$ & Split spoon \\
\hline
\end{tabular}

'Duplucate sampie 
Table 4. Sampling point coordinates and elevations

\begin{tabular}{ccccc}
\hline $\begin{array}{c}\text { Sample } \\
\text { points }\end{array}$ & Northing & Easting & Elevarion & Description \\
\hline 1 & 29637.93 & 53794.74 & 993.15 & SS-1 \\
2 & 29649.38 & 53748.45 & 993.38 & SS-2 \\
3 & 29647.80 & 53775.61 & 992.94 & SS-3 \\
4 & 29655.24 & 53749.27 & 992.89 & SS-4 \\
5 & 29692.20 & 53728.46 & 991.99 & SS-5 \\
6 & 29715.83 & 53806.11 & 990.83 & SS-6 \\
7 & 29736.26 & 53750.44 & 990.23 & SS-7 \\
8 & 29740.92 & 53751.64 & 990.11 & SS-8 \\
9 & 29762.67 & 53743.63 & 989.15 & SS-9 \\
10 & 29750.63 & 53800.75 & 989.27 & SS-10 \\
11 & 29771.56 & 53782.25 & 989.25 & SS-11 \\
12 & 29769.63 & 53801.75 & 989.09 & SS-12 \\
13 & 29644.48 & 53824.19 & 993.18 & SB-1 \\
14 & 29646.85 & 53757.16 & 993.68 & SB-2 \\
15 & 29663.55 & 53748.77 & 992.59 & SB-3 \\
16 & 29684.04 & 53810.91 & 992.51 & SB-4 \\
17 & 29697.74 & 53755.38 & 991.61 & SB-5 \\
18 & 29703.18 & 53831.64 & 991.41 & SB-6 \\
19 & 29710.40 & 53797.84 & 991.47 & SB-7 \\
20 & 29721.00 & 53755.78 & 991.23 & SB-8 \\
21 & 29750.03 & 53831.56 & 989.71 & SB-9 \\
22 & 29762.23 & 53834.07 & 989.19 & SB-10 \\
23 & 29766.24 & 53826.73 & 989.11 & SB-11 \\
24 & 29771.03 & 53806.12 & 989.65 & SB-12 \\
\hline
\end{tabular}






Samples collected for volatile organic analyses were collected first and were not composited. Samples collected at each depth interval for the remaining analytes were placed in a precleaned approved container and homogenized prior to filling sample containers. TCLP metals analyses were only performed if the total concentration of a characteristic metal in a soil sample exceeded 20 times the extract solution regulatory limit on a part per million basis.

A summary of subsurface soil sample numbers, sampling method, and sampling interval is presented in Table 3.

All soil boring locations were marked in the field and later surveyed by a subcontracted registered surveyor. Location and elevation of each boring were surveyed from established benchmarks tied to the Y-12 Plant grid system (Table 4). Surveys were compieted to a horizontal and vertical accuracy of 0.003 $\mathrm{m}(0.01 \mathrm{ft})$.

\section{HEALTH AND SAFETY}

Prior to any on-site activities, all personnel were required to have completed the required 40-h OSHA training and received a medical examination in accordance with 29 CFR 1910.120. Employees were required to be fit-tested for respiratory equipment. Adequate respiratory equipment was kept on site throughout the project, although project activities did not require its use. Before entering the exclusion zone, employees were required to don chemical protective clothing (such as Tyvek" coveralls), impermeable chemical protective gloves and boots or overboots, and safety glasses. During drilling operations hard hats, steel-toed boots, and hearing protection were also required. During steam cleaning operations employees were required to wear hearing protection, chemical protective clothing, safety boots and impermeable overboots, chemical protective gloves, and a full-face respirator with appropriate cartridge.

Monitoring for exposure to specific contaminants, including organic vapors and ionizing radiation, was performed during all intrusive sampling. Monitoring for organic vapors was conducted with an $\mathrm{HNu}$ PI 101 photoionization detector with a $10.2 \mathrm{eV}$ lamp, while monitoring for ionizing radiation was conducted with Ludlum Model 3 instruments with beta/gamma pancake or alpha probes. While mercury was a suspected contaminant on site, it was not monitored for because the very low temperatures during intrusive operations made it nearly impossible for airborne concentrations approaching the threshold limit value to develop. Instruments were calibrated, calibration checked, or response checked daily prior to use. Records of these calibrations were entered in the daily logbook.

Daily background levels for all monitoring instruments were taken at the decontamination area prior to field activities. Background levels for beta/gamma radiation at the decontamination site remained within 30 to 50 counts per minute. Background levels for alpha were $<3$ counts per minute. Airborne vapor background levels were below detection limits for the monitoring equipment. 
Weather conditions provided some unique health and safety problems during the course of the project. Temperatures ranged from $18.7^{\circ} \mathrm{C}\left(40^{\circ} \mathrm{F}\right)$ down to $4.7^{\circ} \mathrm{C}\left(15^{\circ} \mathrm{F}\right)$ with winds of 15 to $20 \mathrm{mph}$ during the coldest temperatures. Precipitation was primarily rain or mist with freezing rain and ice for two days. For $2 \mathrm{~d}$, sampling was reduced to half days by the weather when the site developed a 1 -in. layer of ice after an ice storm. Sand and vermiculite were spread around the drilling locations to provide traction, and pathways of sand and vermiculite were laid out for traction while carrying samples and equipment to and from the Contamination Reduction zone. Cold stress and hypothermia were discussed with the field crew and cold weather clothing was added to the personal protection equipment.

Organic vapor monitoring was performed in the employee breathing zone and within 3 to $5 \mathrm{~cm}$ (1.2 to 2 in.) of the sample material and cuttings. Readings were also taken from the lip of the auger stem to determine the level of potential off-gassing from buried sources. No readings greater than zero were found in the breathing zone.

Levels of beta/gamma radiation ranged from regional background, 30 to 50 counts per minute, to 150 counts per minute at the surface of some sampling locations during drilling. These radiation levels fell off to a background at a depth of $6.5 \mathrm{~cm}$ (2.6 in.). During surface sampling, beta/gamma radiation leveis ranged from regional background to a high of 1000 counts per minute on contact, and samplers were instructed to use the minimum amount of time necessary and sample at the greatest distance possible from these sources. Alpha radiation did not exceed background levels. Immediately following the completion of the project, as an additional precaution, the thermoluminescent dosimeter of the Site Health and Safety Officer was read for exposure because his potential for exposure was the greatest. These personal dosimetry readings proved to be no greater than background for the duration of the Project.

\section{QUALTTY ASSURANCE}

The IDY RCRA Closure Investigation was conducted under the provisions of the QAPjP (Y/ER133), which included sections on field and laboratory quality assurance/quality control (QA/QC). The QAPjP was prepared in accordance with the Energy Systems Environmental Restoration Division Quality Program Plan [ES/ER/TM-4/R3 (Energy Systems 1993b)], all EPA guidance documents, and the Field Sampling Analysis Plan, December 1993.

The QAPjP sought to mitigate potential adverse impacts on the environment, safety and health, and property of the plant and public. The objective of the QAPjP was to create an appropriate QA program whose personnel had sufficient authority to identify problems; to initiate, recommend, or provide solutions to quality problems; to verify solutions; and to ensure that further work was not completed until proper disposition of a nonconformance or deficiency.

The data quality objectives were discussed in the QAPjP and detailed the requirements for QC levels 1,2, and 3 analytical support. The RCRA closure required QC Level 2 analytical support. However, Level 3 support was selected so any future CERCLA investigations at the site would be able to use the data collected. Also, an expanded list of analytes was developed to address any future CERCLA concerns for the site. 


\section{Field QA}

The field QAPjP was initiated with a readiness review to ensure that (1) all work plans and standard operating procedures were approved and controlled; (2) all assigned personnel were trained or a schedule was established to conduct training; (3) the site logistics were handled; (4) the laboratory was ready to accept samples; (5) all other subcontractors were ready to begin work; and (6) the QA system was implemented.

Soil samples were collected, packed, shipped, and handled in accordance with procedures prescribed in the QAPjP. QC samples, including trip blanks, field blanks, equipment rinsate blanks, and field duplicates, were collected at the frequency specified in the QAPjP. Sample custody was documented from the time of collection to data reporting, and samples were labeled with the required information. All sampling devices and equipment were decontaminated per specified procedures. New sample containers were supplied by the ASO. Of these bottles, $1 \%$ are tested for contamination, and a record of these results is maintained by the ASO. Records of all field activities were maintained in field logbooks and on appropriate data forms.

The quality of field records was checked by inspection and verification of entered data. The field notebooks were copied and dual-stored, with one copy kept in a fireproof cabinet. Additional information concerning the surveyed locations and elevations of sampling points were added after field activities were completed. Logbooks will be stored in the SAIC Central Records Facility at the end of the project.

All scheduled measuring and test equipment (M\&TE) calibration was performed, and where malfunction of equipment was suspected, the equipment was removed from service. Calibration data were maintained in the Health and Safety/M\&TE logbook.

\section{Laboratory OA}

The laboratory Statement of Work and the QAPjP defined the procedures to be followed in laboratory custody, analysis, and handling of samples and data for the IDY investigation. Level C data quality was maintained, providing appropriate detection limits, a wide range of calibrated analyses, matrix recovery information, laboratory process control information, and known precision and accuracy.

Samples were analyzed using the methods and protocols found in Test Methods for Evaluaring Solid Wastes, EPA SW-846 (EPA 1986); EPA Contract Laboratory Program, Statement of Work for Inorganic Analysis, ILM 03.0 (cyanide) (EPA 1993); and Y-12 ASO Procedures.

Calibration of laboratory M\&TE was performed in accordance with the Y-12 ASO Standard Operating Procedure Y/P65-9071 and as described in individual analytical operating procedures or instrument manuals. Calibration is recorded as per Y-12 ASO Standard Operating Procedures entered into the maintenance logbook as needed and as per Y-12 ASO Standard Operating Procedure Y/P65-9069. 
APPENDIX II

SITE CHARACTERIZATION DATA SUMMARY 
IDY SITE CHARACTERIZATION

DATA SUMMARY

(ND = Not Detected $)$

\begin{tabular}{|c|c|c|c|c|c|c|c|c|c|c|c|c|c|}
\hline \multirow[b]{2}{*}{ Sample Location } & \multicolumn{13}{|c|}{ Contaminants of Concern (ppm or $\mathrm{mg} / \mathrm{kg}$ ) } \\
\hline & Arsenic & Cadmium & Chromium & Cyanide & Freon & $\begin{array}{l}\text { Lead/ } \\
\text { TCLP }\end{array}$ & Mercury & $\begin{array}{l}\text { Methylene } \\
\text { Chloride }\end{array}$ & Nickel & $\begin{array}{c}\text { Perchloroet } \\
\text { hylene }\end{array}$ & PCBs & Selenium & Silver \\
\hline$\frac{\text { Surface Sample }}{\text { SS-1 }}$ & 6.9 & 0.16 & 32.6 & ND & ND & 40.0 & ND & ND & 19.5 & ND & ND & NI) & 2.4 \\
\hline SS-2 & 1 & 0.31 & 5.6 & ND & ND & 10.1 & ND & ND & 11.6 & ND & 6.3 & ND & 1 \\
\hline SS-3 & 3.2 & 1.1 & 6.8 & ND & ND & 14.1 & 0.71 & ND & 6.6 & ND & 0.166 & ND & 0.98 \\
\hline SS-4 & 2.1 & 0.74 & 7.0 & ND & ND & 10.8 & 1.1 & ND & 12.3 & ND & 1.1 & ND & 0.41 \\
\hline SS-5 & 1.8 & 2.1 & 39.7 & ND & ND & $180 / 0.09$ & 12.3 & ND & 105 & ND & 6.7 & ND & 1.7 \\
\hline SS-6 & 2.9 & 0.26 & 58.9 & ND & ND & 23.3 & ND & ND & 15.1 & ND & 0.067 & ND & 0.56 \\
\hline SS-7. & 3.5 & 2.6 & 30.7 & ND & ND & $132 / 0.08$ & 22.6 & ND & 89.1 & ND & 11.9 & ND & 1.3 \\
\hline SS-8 & 3.8 & 1.7 & 29.7 & IND & $\mathrm{ND}$ & $154 / 0.09$ & 27.9 & ND & 67.1 & ND & 1.8 & ND & 2.8 \\
\hline SS-9 & 2.8 & 5.3 & 33.0 & $\mathrm{ND}$ & ND & $192 / 0.14$ & $106^{*}$ & ND & 153 & ND & 11.6 & ND & 4.8 \\
\hline SS-10 & 8.2 & 0.82 & 197.0 & ND & ND & 58.6 & 3.1 & ND & 26.6 & ND & 0.39 & ND & 0.94 \\
\hline SS-11 & 2.6 & 0.11 & 20.1 & $\mathrm{ND}$ & ND & 54.9 & 2.4 & ND & 22.6 & ND & 0.27 & ND & 0.57 \\
\hline SS-12 & 3.2 & 0.49 & 64.7 & ND & $\mathrm{ND}$ & 16.6 & 2.1 & ND & 11.6 & ND & 0.137 & ND & 0.41 \\
\hline$\frac{\text { Subsurface }}{\mathrm{SB}-1 \quad 1-3 \mathrm{it}}$ & 4.1 & $219^{*}$ & 64.5 & ND & ND & $189 / .03$ & 0.67 & ND & 42.4 & ND & NI) & NI) & 5.6 \\
\hline SB-2 $\quad 1-3 \mathrm{ft}$ & 2.9 & 0.18 & 42.5 & $\mathrm{ND}$ & ND & 33.7 & 1.5 & ND & 42.9 & ND & 0.23 & ND & .53 \\
\hline $\mathrm{SB}-2 \quad 3-5 \mathrm{ft}$ & 3.4 & 0.06 & 31.7 & ND & ND & 16 & ND & ND & 42.5 & ND & ND & ND & ND \\
\hline $\mathrm{SB}-2 \quad 5-9 \mathrm{ft}$ & 10 & 0.46 & 50.8 & ND & ND & 44.4 & ND & ND & 53.3 & ND & 0.07 & ND & $\mathrm{ND}$ \\
\hline SB-2 $10-12$ ft & 7.5 & 0.22 & 46.9 & ND & ND & $124 / .07$ & ND & ND & 69.3 & ND & ND & ND & .51 \\
\hline SB-3 $\quad 1.3 \mathrm{ft}$ & 5.9 & .09 & 31.9 & ND & ND & 35.7 & .26 & ND & 32.3 & 0.19 & ND & ND & .96 \\
\hline SB-3 $\quad 3-5 \mathrm{ft}$ & 2.9 & .05 & 38.1 & ND & ND & 25.8 & ND & ND & 43.8 & 0.057 & 0.04 & ND & .5 \\
\hline SB-3 $\quad 5-7 \mathrm{ft}$ & 3.4 & .11 & 31 & ND & ND & 54.6 & ND & ND & 28.1 & 0.011 & ND & ND & .35 \\
\hline
\end{tabular}




\begin{tabular}{|c|c|c|c|c|c|c|c|c|c|c|c|c|c|}
\hline \multirow[b]{2}{*}{ Sample Location } & \multicolumn{13}{|c|}{ Contaminants of Concern ( $\mathrm{ppm}$ or $\mathrm{mg} / \mathrm{kg}$ ) } \\
\hline & Arsenic & Cadmium & Chromium & Cyanide & Freon & $\begin{array}{l}\text { Lead/ } \\
\text { TCLP }\end{array}$ & Mercury & $\begin{array}{l}\text { Methylene } \\
\text { Chloride }\end{array}$ & Nickel & $\begin{array}{c}\text { Perchloroel } \\
\text { hylene }\end{array}$ & PCBs & Selenium & Silver \\
\hline SB-4 $\quad 1-2 \mathrm{ft}$ & 1.8 & 14.6 & 36.2 & ND & $\mathrm{ND}$ & 13.3 & 1.3 & ND & 33.1 & ND & ND & ND & .7 \\
\hline SB-5 $\quad 1-3 \mathrm{ft}$ & 7.3 & .12 & 32.2 & ND & ND & 41.6 & ND & ND & 23.3 & 0.11 & 0.11 & ND & .81 \\
\hline SB-5 $\quad 3-5 \mathrm{ft}$ & 4.3 & ND & 49.4 & ND & $\mathrm{ND}$ & 13.1 & ND & ND & 41.1 & ND & 0.17 & ND & .33 \\
\hline SB-5 $\quad 5-7 \mathrm{ft}$ & 1.3 & ND & 45.5 & ND & ND & 32.3 & ND & ND & 39.3 & ND & ND & ND & ND \\
\hline SB-5 $\quad 10-12 \mathrm{ft}$ & 14 & 0.05 & 18.4 & ND & ND & 45.0 & .3 & ND & 12.9 & ND & ND & ND & ND \\
\hline $\mathrm{SB}-6 \quad 1-3 \mathrm{ft}$ & 2.9 & 1.5 & 47.5 & ND & ND & 23.6 & 1.9 & ND & 44.5 & ND & $\mathrm{ND}$ & ND & ND \\
\hline SB-6 $\quad 3-5 \mathrm{ft}$ & 2.2 & ND & 38.2 & ND & ND & 14 & ND & ND & 36.9 & ND & $\mathrm{ND}$ & ND & ND \\
\hline SB-6 $\quad 5-7 \mathrm{ft}$ & 2 & .24 & 45.5 & ND & ND & 11.1 & .53 & ND & 40.4 & ND & ND & ND & ND \\
\hline SB-7 $\quad 3-5 \mathrm{ft}$ & 4.1 & .04 & 61.7 & ND & ND & 24.5 & ND & ND & 36.1 & ND & $\mathrm{ND}$ & ND & NI \\
\hline SB-7 $\quad 5-7 \mathrm{ft}$ & 2.8 & .02 & 43.8 & ND & ND & 15.2 & ND & ND & 30.4 & ND & ND & ND & .39 \\
\hline $\mathrm{SB}-7 \quad 10-12 \mathrm{ft}$ & 4.8 & .04 & 34.5 & ${ }_{1} \mathrm{ND}$ & ND & 40.1 & ND & ND & 24.2 & ND & ND & ND & .41 \\
\hline $\mathrm{SB}-7 \quad 15-17 \mathrm{ft}$ & 17.6 & .73 & 28.3 & ND & ND & 51 & ND & ND & 20.1 & ND & ND & ND & .39 \\
\hline SB-8 $\quad 1-3 \mathrm{ft}$ & 4.3 & .89 & 27.7 & ND & ND & 30.8 & 1.2 & ND & 36.6 & ND & 0.63 & ND & .58 \\
\hline SB-8 $\quad 3-5 \mathrm{ft}$ & 2.7 & .04 & 41.6 & ND & ND & 27.8 & 29 & ND & 48.2 & ND & 0.07 & ND & .64 \\
\hline SB-8 $\quad 5-7 \mathrm{ft}$ & 2.3 & .05 & 44.6 & ND & ND & 15.1 & ND & ND & 36 & ND & 0.05 & ND & .5 \\
\hline SB-8 $\quad 10-12 \mathrm{ft}$ & 16.5 & ND & 27.3 & ND & ND & 32.4 & ND & ND & 10.4 & ND & ND & 1 & .54 \\
\hline SB-8 $15-17 \mathrm{ft}$ & 3.8 & .08 & 24.7 & ND & ND & 19.7 & ND & ND & 13 & ND & ND & ND & .36 \\
\hline SB-9 $\quad 1-3 \mathrm{ft}$ & 5.1 & 1.4 & 67.1 & ND & ND & 66 & .83 & ND & 29.2 & ND & ND & $N D$ & .67 \\
\hline SB-9 $\quad 3-5 \mathrm{ft}$ & 2.1 & .13 & 30.8 & ND & ND & 9.5 & ND & ND & 20.3 & ND & ND & ND & .22 \\
\hline SB-9 $\quad 5-7 \mathrm{ft}$ & .93 & .04 & 37 & ND & ND & 13.3 & .2 & ND & 26.1 & ND & ND & ND & .23 \\
\hline SB-9 $\quad 10-12 \mathrm{ft}$ & 2.2 & .12 & 48.6 & ND & ND & 14.4 & .22 & ND & 30.3 & ND & ND & ND & .25 \\
\hline SB-9 $\quad 15-17 \mathrm{ft}$ & 9.2 & 0.1 & 37.2 & ND & ND & 56.8 & .22 & ND & 17.6 & ND & ND & ND & .25 \\
\hline SB-10 $\quad 1-3 \mathrm{ft}$ & 11.7 & .96 & 46.6 & ND & ND & 41.2 & .45 & ND & 46.5 & ND & ND & ND & .93 \\
\hline SB-10 $\quad 3-5 \mathrm{ft}$ & 3.1 & .22 & 30.6 & ND & ND & 15 & .2 & ND & 42.9 & ND & ND & ND & ND \\
\hline
\end{tabular}




\begin{tabular}{|c|c|c|c|c|c|c|c|c|c|c|c|c|c|}
\hline \multirow[b]{2}{*}{ Sample Location } & \multicolumn{13}{|c|}{ Contaminants of Concern ( $\mathrm{ppm}$ or $\mathrm{mg} / \mathrm{kg}$ ) } \\
\hline & Arsenic & Cadmium & Chromium & Cyanide & Freon & $\begin{array}{l}\text { Lead/ } \\
\text { TCLP }\end{array}$ & Mercury & $\begin{array}{l}\text { Methylene } \\
\text { Chloride }\end{array}$ & Nickel & $\begin{array}{l}\text { Perchloroet } \\
\text { hylene }\end{array}$ & PCBs & Selenium & Silver \\
\hline SB-10 $\quad 5-7 \mathrm{ft}$ & 1.2 & .1 & 44.7 & ND & ND & 14.2 & ND & ND & 33.9 & ND & ND & ND & $\mathrm{ND}$ \\
\hline SB-10 $10-12 \mathrm{ft}$ & 8 & .14 & 54.9 & ND & ND & 61.8 & ND & ND & 25.4 & ND & ND & ND & .93 \\
\hline SB-10 $15-17 \mathrm{ft}$ & 3.3 & .06 & 40.4 & ND & ND & 25.5 & .23 & ND & 38.9 & ND & ND & ND & ND \\
\hline SB-11 $1-3 \cap$ & 5.5 & 1.8 & 37.8 & ND & ND & 45.3 & .69 & .007 & 33 & ND & 0.14 & ND & ND \\
\hline SB-11 $3-5 \mathrm{ft}$ & 2.1 & .12 & 26.2 & ND & ND & 16 & .26 & .004 & 23 & ND & ND & ND & ND \\
\hline SB-11 $7-9 \mathrm{ft}$ & 2.2 & .36 & 46.4 & ND & ND & 12.9 & .24 & .006 & 46.5 & ND & ND & ND & ND \\
\hline SB-11 $10-12 \mathrm{ft}$ & 8.9 & .07 & 50.6 & ND & ND & 70.6 & .29 & .008 & 17.8 & ND & ND & ND & ND \\
\hline SB-11 15-17 ft & 4.2 & .12 & 32.3 & ND & ND & 23.7 & .22 & .005 & 23.5 & ND & $\mathrm{ND}$ & ND & ND \\
\hline SB-12 $1-3 \mathrm{ft}$ & 4 & 4.4 & 27.2 & ND & ND & 45.2 & .66 & ND & 14.6 & ND & ND & ND & .73 \\
\hline SB-12 $3-5 \mathrm{ft}$ & 2.4 & 1 & 20.9 & ND & ND & 21.7 & .23 & ND & 16.9 & ND & 0.04 & ND & .62 \\
\hline SB-12 $5-7 \mathrm{ft}$ & 1.7 & .6 & 33.9 & ND & ND & 35.4 & .59 & ND & 23.3 & ND & 0.09 & ND & .49 \\
\hline SB-12 $10-12 \mathrm{ft}$ & 3.8 & .16 & 28.5 & ND & ND & 31.4 & .65 & ND & 21.8 & ND & ND & ND & .49 \\
\hline SB-12 $15-17 \mathrm{ft}$ & 6.1 & .24 & 31 & ND & ND & 29 & .2 & ND & 29.2 & ND & ND & ND & .49 \\
\hline
\end{tabular}

